The Classical Quarterly

http://journals.cambridge.org/CAQ

Additional services for The Classical Quarterly:

Email alerts: $\underline{\text { Click here }}$

Subscriptions: $\underline{\text { Click here }}$

Click here

Terms of use : $\underline{\text { Click here }}$

\title{
THE WOMEN OF RULING FAMILIES IN ARCHAIC AND CLASSICAL
} GREECE

LYNETTE G. MITCHELL

The Classical Quarterly / Volume 62 / Issue 01 / May 2012, pp 1 - 21

DOI: 10.1017/S0009838811000590, Published online: 24 April 2012

Link to this article: http://journals.cambridge.org/abstract_S0009838811000590

How to cite this article:

LYNETTE G. MITCHELL (2012). THE WOMEN OF RULING FAMILIES IN ARCHAIC AND CLASSICAL GREECE. The Classical Quarterly, 62, pp 1-21 doi:10.1017/S0009838811000590

Request Permissions : $\underline{\text { Click here }}$ 


\section{THE WOMEN OF RULING FAMILIES IN ARCHAIC AND CLASSICAL GREECE*}

Despite the explosion of interest in women and the role of women in Greece, the wives, consorts and daughters of Greek rulers in the Archaic and Classical periods have rarely achieved much serious attention. This is hardly surprising, however, as little real consideration has been given to individual rule as a legitimate phenomenon in the Archaic and Classical periods, let alone to individual rulers, since it is still often assumed that personal rule had dwindled with the rise of the polis, if it had ever existed at all. ${ }^{1}$ The so-called 'tyrants' of the Archaic period are generally considered to be a separate phenomenon from any earlier rulers, and are sometimes characterized as having violently seized control and holding rule unconstitutionally as despots over the unwilling. ${ }^{2}$ Thucydides certainly makes a distinction between the patrikai basileiai ${ }^{3}$ of former times who had limited rights and responsibilities

* A version of this paper was presented as the Dorothy Buchan Memorial Lecture at Leicester in October 2009, and an earlier draft was also presented to the Classical Association at Exeter. I would like to thank both audiences for their critical comment and encouragement. I would also like to thank Prof. Elizabeth Carney, Dr David Harvey, Prof. Deborah Lyons, Prof. Daniel Ogden, and Prof. Peter Rhodes for specific comments and help with drafts of this paper, and Prof. Barbara Borg for discussing it with me at various stages.

${ }^{1}$ e.g. C.G. Starr, 'The decline of the early Greek kings', Historia 10 (1961), 129-38; R. Drews, Basileus. The Evidence for Kingship in Geometric Greece (New Haven, 1983) (who also does not want to think of the Archaic basileis as 'kings'); P. Carlier, La royauté en Grèce avant Alexandre (Strasbourg, 1984), 495-6 (although he notes the continuance of kingship at Cyrene into the fifth century); S. Morris, 'Imaginary kings: alternatives to monarchy in early Greece', in K. Morgan (ed.), Popular Tyranny: Sovereignty and its Discontents (Austin, 2003), 1-24, who makes the case against any form of personal rule in the periods (both Bronze Age and early Iron Age) before the tyrants.

${ }^{2}$ On 'the rise of the tyrants' as a new and distinct phase of political development in the seventh century: e.g. R. Osborne, Greece in the Making, 1200-479 BC (London and New York, 2009²), 180-5; J. Hall, A History of the Archaic Greek World, ca. 1200-479 BCE (Oxford, 2007), 137-43 (although Hall would interpose a period of aristocracy between a first period of 'big men'/chieftains [basileis] and a second period of 'big men' [tyrannoi]). However, not all think the so-called tyrants should be distinguished from other Archaic rulers. There is an increasing trend towards seeing Archaic politics as elite politics. For example: L. Foxhall, 'A view from the top: evaluating the Solonian property classes', in L.G. Mitchell and P.J. Rhodes (edd.), The Development of the Polis in Archaic Greece (London and New York, 1997), 113-36; G. Anderson, 'Before turannoi were tyrants: rethinking a chapter of early Greek tyrants', ClAnt 24 (2000), 173-222; E. Stein-Hölkeskamp, 'The tyrants', in K.A. Raaflaub and H. van Wees (edd.), A Companion to Archaic Greece (Malden, MA, Oxford and Chichester, 2009), 100-16. On Archaic tyrants as unconstitutional rulers: e.g. A. Andrewes, The Greek Tyrants (London, Melbourne, Sydney and Auckland, 1974²); M. Dillon and L. Garland (edd.), Ancient Greece: Social and Historical Documents from Archaic Times to the Death of Alexander the Great (Abingdon, 20103), 256. Not all assessments of tyrants are negative: e.g A. Snodgrass, Archaic Greece: The Age of Experiment (London, Melbourne and Toronto, 1980), 96-7; M. White, 'Greek tyranny', Phoenix 9 (1955), 1-18; J. Salmon, 'Lopping off the heads? Tyrants, politics and the polis', in Mitchell and Rhodes (edd.), 60-73.

${ }^{3}$ Patrikai basileiai is usually translated 'hereditary kingship' (see e.g. S. Hornblower, $A$ Commentary on Thucydides [Oxford, 1991-2008], 1.42), but patrikai is probably best rendered 'ancestral', since Thucydides is trying to contrast what he sees as an ancient institution with 
(epi rhêtois gerasi) and the tyrannoi who emerged as the Greek cities became wealthier (1.13.1), ${ }^{4}$ but self-interested tyranny was a theme that Thucydides was keen to exploit in his interpretation of the politics of the late fifth century. ${ }^{5}$ In the fourth century Aristotle also said that, while a number of kinds of basileis were possible (Pol. 3, 1284a3-17, 1284b25-34, 1285a3-b35), in his own time rule by one man could only be tyranny, ${ }^{6}$ since - measured against his narrow definition of what constituted an ideal polis - it must be rule of the unwilling in the interests of the ruled (e.g. Pol. 3, 1279b6-7, 5, 1313a3-8). Nevertheless, increasingly it seems to be agreed, as Sian Lewis has recently noted, that the boundaries between tyranny and other personal kinds of rule are more difficult to pin down than either Aristotle or Thucydides might suggest. ${ }^{7}$

Even leaving aside the Homeric rulers and the basileis and tyrannoi of Greek tragedy, ${ }^{8}$ the Archaic and Classical periods are littered with rulers (whether they were known as basileis or tyrannoi), ${ }^{9}$ who made legitimate claims to rule based

a more recent development. In any case (whether or not one distinguishes between an earlier form of personal rule and the tyrannoi), it is unclear to what extent (in the Archaic period at least) rule was conceived as strictly hereditary in the sense of being passed from father to son (cf. Osborne [n. 2], 137-8, 143-4), although most rulers would probably want to pass the rule through the family. Succession passing between brothers, or being shared among family members, was common. The so-called epicracy of the Dinomenids in Sicily, which was familybased rule, is discussed below, but the phenomenon of sharing rule within the family was also practised in a number of other places around the Greek world in our period. The lineage of the sceptre of Agamemnon itself is telling: given to Pelops, it is passed to his son Atreus, who left it for his brother Thyestes, who then gives it to his nephew Agamemnon (Hom. Il. 2.100-8).

${ }^{4}$ On 'tyranny' and wealth: L. Kurke, The Traffic in Praise. Pindar and the Poetics of Social Economy (Ithaca, NY and London, 1991), 175-82 (although it is not clear that megaloprepeia should be limited to tyrants or whether it is being promoted by Pindar, Herodotus and others as a virtue of rulers in general). R. Seaford (although he does not critique tyranny as an institution and assumes it must exercise absolute power) makes much of the link between tyranny and wealth: Money and the Early Greek Mind. Homer, Philosophy, Tragedy (Cambridge, 2004), esp. 214.

${ }^{5}$ L.G. Mitchell, Panhellenism and the Barbarian in Archaic and Classical Greece (Swansea, 2007), 141-6; ead., 'Thucydides and the monarch in democracy', Polis 25 (2008), 1-30.

${ }^{6}$ He dismisses the Spartan basileis as permanent generals and not proper constitutional rulers: Pol. 3, 1285a3-10, 1285b33-5, 1286a2-5; cf. 3, 1287a3-8, 4, 1289a41-b1.

${ }^{7}$ S. Lewis, 'Introduction', in ead. (ed.), Ancient Tyranny (Edinburgh, 2006), 1-14.

${ }^{8}$ Paul Cartledge has recently noted that the Homeric texts are too problematic to be able to excavate much sense of what real-life rulers would have been like in the early Archaic period: Ancient Greek Political Thought in Practice (Cambridge, 2009), 29-40; see, however, K.A. Raaflaub, 'A historian's headache. How to read 'Homeric society?', in N. Fisher and H. van Wees (edd.), Archaic Greece: New Approaches and New Evidence (London and Swansea, 1998), 169-93. For attempts to argue the case for Archaic kingship on the basis of the Homeric texts, see e.g. Carlier (n. 1), 137-230 and H. van Wees, Status Warriors. War, Violence and Society in Homer and History (Amsterdam, 1992), 32-6, 281-94. Others think that kingship in Homer is empty of any real content (so that although Homer was aware of the institution it had no purchase in either his real or imaginary worlds): see esp. A.G. Geddes, 'Who's who in Homeric society', CQ 34 (1984), 17-36, esp. 28-36; J. Halverson, 'The succession issue in the Odyssey', $G \& R 33$ (1986), 119-28. B. Qviller argues, on the basis of the Homeric texts, that kingship in the Archaic period was dysfunctional and so disappeared: 'The dynamics of Homeric society', SO 56 (1981), 109-55. W. Thalmann argues that the Homeric/Archaic kings are not kings 'in our sense' (which only begs the question): The Swineherd and the Bow. Representations of Class in the Odyssey (New York, 1998), 246 with n. 18. For kingship in tragedy, see esp. M. Griffith, 'The king and eye: the rule of the father in Greek tragedy', PCPhS 44 (1998), 22-86. For tyrants in tragedy: R. Seaford, 'Tragic tyranny', in K. Morgan (ed.), Popular Tyranny: Sovereignty and its Discontents (Austin, 2003), 95-115.

${ }^{9}$ It seems clear that originally the term tyrannos did not have pejorative overtones and that, although e.g. Solon rejects tyranny (frr. 32, 33, 34.6-8 West) and Thucydides suggests it is an 
on heredity, cult or military prowess (or combinations thereof). ${ }^{10}$ And these rulers had wives and consorts. It is the position of these women (though often only barely visible) and their roles that I would like to discuss here. It is sometimes said (when they are noticed) that the wives of rulers had no defined role, and so were politically insignificant. However, as shall be seen, the importance of these women should not be underestimated.

This essay will begin by considering Olympias, one of the best known and most studied consorts in the classical world, who became a powerful political and religious figure, and is often regarded as the exemplum for the queens of the Hellenistic period. Olympias' career highlights a number of important themes - her role in a polygamous court, her political effectiveness on the wider Greek stage, and her relationship to heroism - which will then be shown to be features of the women of ruling families across Greece in the earlier periods as well. In this way the ruling women of Archaic and Classical Greece will show themselves to be not only significant figures in their own households and communities - even if they were also considered anomalous, challenging and dangerous to the proper order of political life - but also part of a larger phenomenon of basileia which was not just Hellenistic and Macedonian, but also deeply embedded in Greek political culture.

\section{OLYMPIAS: A PARADIGMATIC QUEEN?}

Olympias' political importance arose out of her position as the mother of Alexander, rather than as the wife of Philip. Daughter of Neoptolemus, basileus of the Molossians, Olympias married Philip II of Macedon (as one of seven wives: Satyrus ap. Ath. 13.577b-e) and was the mother of Alexander the Great, who was born

improper form of ruling $(2.63 .2,3.37 .2)$, Pindar, Aeschylus, Sophocles and Herodotus seem to use basileus and tyrannos interchangeably (e.g. Andrewes [n. 2], 21-8; White [n. 2], 2-4; although note also A. Ferill, 'Herodotus on tyranny', Historia 27 [1978], 385-98, who thinks Herodotus is more particular, and more pointed, in his use of terminology of personal rule than is usually allowed). In the Archaic and Classical periods rulers themselves very rarely used titles. For example, although others (like Pindar) may have called the Dinomenids basileis (Pind. Ol. 1.23 [cf. 114], Pyth. 1.60, 3.70) and tyrannoi (Pind. Pyth. 3.84-6), the rulers in Sicily tended to avoid titles. Nevertheless, on the Delphic Charioteer one of the Deionominds styled themselves 'One who is Lord over Gela', but this was erased and reinscribed without a title (F. Delphes 3.4.452 and n. 20 below). Dionysius I called himself archōn of Sicily (e.g. P.J. Rhodes and R. Osborne, Greek Historical Inscriptions, 404-323 B.c. [Oxford, 2003], nos. 10, 33, 34), but did not use the title basileus, contra S. Oost, 'The tyrant kings of Syracuse', CPh 71 (1976), 224-36. Alexander the Great did begin to style himself as basileus on inscriptions, and on some coins issued in Asia Minor. Decrees: restored in SEG 36.626, dated to 335 B.C.; A. Heisserer (Alexander the Great and the Greeks: The Epigraphic Evidence [Norman, 1980]) dates the title in Rhodes and Osborne (above), no. 83, basileōs Alexandrō, to 335 B.c.: 50-1, 91-2 with nn. 30-1; see also E. Borza, Before Alexander: Constructing Early Macedonia (Claremont, 1999), 11-15. Coins: N.G.L. Hammond, The Macedonian State: The Origins, Institutions and History (Oxford, 1989), 199.

${ }^{10}$ It is interesting that most rulers could not maintain absolute and unrestrained control, but did need to provide some defence of their rule. Even Dionysius I of Syracuse, who in antiquity was compared to the Persian king (and may also have modelled his rule on Persia: L.J. Sanders, Dionysius I of Syracuse and Greek Tyranny [London, New York and Sydney, 1987], 7-8) was elected as general with full powers, and felt the need to link himself with Gelon, who also had had popular support (see n. 57 below). The nature of rulers and ruling in Archaic and Classical Greece is a subject that needs a full treatment, to which I intend to return in an independent study. 
in 356 B.c. At the time of Philip's death Alexander was his only viable successor, since Philip's other son, Philip Arrhidaeus by his Thessalian wife Philinna, had a mental disability which removed him from the competition. Although in Macedon there was no chief wife and succession was based not on primogeniture but on influence, ${ }^{11}$ as Elizabeth Carney has shown, Philip did single out Alexander as his heir at least by the time the boy was sixteen (Plut. Alex. 9.1). That Olympias at this time was also being preferred is indicated by the inclusion of her statue, along with statues of Alexander, Eurydice (Philip's mother) and Amyntas (Philip's father), in the Philippeum which he constructed at Olympia after his victory at Chaeronea (Paus. 5.17.4, 20.9-10). ${ }^{12}$

But the position of Olympias and Alexander was completely destabilized by Philip's marriage to the Macedonian Cleopatra in 337. Cleopatra was the niece of Attalus, an influential nobleman at Philip's court, and represented an important counter-faction to Olympias and Alexander, especially if Cleopatra were to have a son by Philip. Even in antiquity it was thought (though possibly incorrectly) that Olympias was implicated in Philip's murder in the following year at the marriage celebrations for their daughter (another Cleopatra), who was marrying her uncle, Olympias' brother, the king of Molossia (Plut. Alex. 10.5; Justin 9.7.9-10). ${ }^{13}$ Whatever her involvement in Philip's assassination, after his death she probably arranged the murder of Cleopatra (the niece of Attalus) and her baby (Justin 9.7.12; Plut. Alex. 10.7; Paus. 8.7.7). ${ }^{14}$

With her son in control in Macedon (and soon absent in Asia), Olympias' position in Macedon grew strong, in both political and religious spheres. Whether or not Alexander appointed her to any official position, it is clear that she acted in public matters both in Macedon, with Antipater (the officially appointed regent during Alexander's absence), and also in Molossia. ${ }^{15}$ She is said to have written with Antipater to Athens to request Harpalus' extradition when Alexander's erstwhile treasurer fled there with the funds (Diod. Sic. 17.108.7). She was also in a strong enough position in the late $330 \mathrm{~s}$ to refuse the Athenians access to the sanctuary at Dodona (cf. Hyp. Eux. 19-26), which seems to have been the principal seat of the Molossian court at the time. ${ }^{16}$ She is also known together with her daughter to have purchased grain from Cyrene during the famine sometime in the early 320s, probably on behalf of both the Molossians and the Macedonians (their personal names are listed along with the names of cities), and possibly as a public benefaction $(S E G 9.2=\mathrm{RO}$ no. 96$) .{ }^{17}$

${ }^{11}$ E. Carney, Women and Monarchy in Macedonia (Norman, 2000), 8-37. On succession, see also L.G. Mitchell, 'Born to rule? The Argead royal succession', in W. Hekel, P. Wheatley and L. Tritle (edd.), Alexander's Empire: Formulation to Decay (Claremont, 2007), 61-74.

${ }^{12}$ E. Carney, Olympias: Mother of Alexander the Great (London, 2006), 49-51. P. Schultz argues persuasively that the building and the statues were one commission: 'Leochares' Argead portraits in the Philippeion', in P. Schultz and R. von den Hoff (edd.), Early Hellenisitic Portraiture: Image, Style, Context (Cambridge, 2007), 208-13.

${ }^{13}$ For the extensive bibliography on the murder of Philip (and Olympias' possible involvement), see esp. E. Carney, 'The politics of polygamy: Olympias, Alexander and the murder of Philip', Historia 41 (1992), 169-89, although Carney thinks that Olympias was too vulnerable to have committed the act.

${ }^{14}$ Carney (n. 12), 43-7.

${ }^{15}$ Ibid. 49-52.

${ }^{16}$ Ibid. 8, 142 n. 34.

${ }^{17}$ For the problems surrounding when and why the grain was distributed, see Rhodes and Osborne (n. 9), 488-93. 
Olympias was also politically impressive as the champion of her grandson, Alexander IV. She marched with an army to war with Dionysiac tympana (though she did not fight: Duris of Samos, FGrH 76 F 52) ${ }^{18}$ against the wife of Philip Arrhidaeus, Adea Eurydice (Philip's daughter by his Illyrian wife, and so Arrhidaeus' half-sister). When the army came over to Olympias (Diod. Sic. 19.11.2; Justin 14.5.10), she had Philip and Adea put to death (Diod. Sic. 19.11.4-9), since even as co-rulers they represented a possible alternative to her grandson. She was also responsible for the massacre of a large number of Cassander's supporters (Diod. Sic. 19.11.8). Plutarch suggests she was involved in witchcraft, and had been responsible for Arrhidaeus' deficiencies (Alex. 77.7-8). ${ }^{19}$ She was eventually assassinated herself after surrendering to Cassander in 315 B.C.

Olympias became a significant political and religious figure in both Macedon and Molossia. Born into a ruling household which traced its descent from Achilles, Olympias, as Carney has so clearly demonstrated, seems to have understood her role not only as sharing in the responsibilities of ruling (which Philip also seems to have supported by including the chryselephantine statue of her in the Philippeum), but also gloriously and determinedly living out, and living up to, her heroic ancestry. At her death, Diodorus says she did not utter either anything unworthy of her birth or anything 'womanly' (19.51.5).

Olympias has usually been interpreted as providing the paradigm for the queens and consorts of the Hellenistic world. However, looking at her in another way, Olympias also represents a culmination of themes and patterns which emerge from the study of the women of ruling households in earlier periods. Olympias sits on the cusp of the Classical and Hellenistic periods, but rather than marking the beginning of a new trend for the Hellenistic period of powerful ruling women, as we shall see, she represents only one point in a much bigger picture. Ruling women in Archaic and Classical Greece (though they so rarely appear from behind their veils) also demonstrate their significance in terms of their role in securing the succession (not passively through child-bearing but actively through the machinations that decided whose son would rule), their part in the negotiations of power (both formal and informal), and their share in the heroic heritage of rulers. In the rest of this essay we will therefore turn to considering the role of women in the households of other ruling families in the Archaic and Classical periods, their political significance within the wider community, and finally their share in the heroic status of rulers.

\section{WOMEN, MARRIAGE AND THE HOUSEHOLDS OF RULING FAMILIES}

Marriages in ruling families were political events, and it is often noted that Archaic rulers in particular connected their families through networks of marriages. For instance, Cylon of Athens (though only an attempted tyrant) was married to the daughter of Theagenes of Megara, who at the end of the seventh century supported

${ }^{18}$ Carney (n. 12), 74.

${ }^{19}$ Ibid. 92-3. See also D. Ogden, 'A war of witches at the court of Philip II?', AM 7 (2007), 357-69, who argues that both Philinna and Olympias, wives of Philip, were labelled as witches as a common accusation made in the 'jostling for position' between rival polygamous wives. 
Cylon in his bid to hold the Athenian acropolis (Thuc. 1.126.3, 5). Such political marriages were not always straightforward, however. In Sicily, the Emmenids of Acragas and the Dinomenids of eastern Sicily bound themselves together by marriage, when Theron of Acragas gave his daughter Demarete to Gelon, the ruler of Syracuse; but on his death Gelon passed the rule of Syracuse to one brother, Hieron (Diod. Sic. 11.38.3), and his army and his wife (according to Timaeus) to another, Polyzalus (who may also have now ruled Gela).$^{20}$ Polyzalus together with Theron and his son Thrasydaeus prepared to go to war against Hieron, although there was finally a resolution in which Simonides the poet seems to have played a part (Timaeus, FGrH 566 F 93b; Diod. Sic. 11.48.3-7; $\Sigma$ Pind. Ol. 2.29c-d) ${ }^{21}$

That is not to say royal marriages for love (or at least desire) were impossible. Plutarch in the Roman period could imagine (rather naively) that Philip II of Macedon married both Olympias and his final bride Cleopatra, the niece of the powerful Macedonian Attalus, for love (Alex. 2.2, 9.6). In our period Herodotus says that erōs stung the Spartan Ariston, who divorced his second wife so that he could marry the wife of his friend (6.62-3.1). We should probably assume that he had also divorced his first wife (cf. Hdt. 6.61.2), since Herodotus says elsewhere that it was not customary for Spartans to take more than one wife (5.40.2). Another Spartan Anaxandrides, however, took a second wife (though this was deliberately polygamous) because he did not want to divorce his first wife when the ephors told him he must because she was childless (Hdt. 5.39-41).

Endogamy was practised widely in the Greek world in order to keep wealth in the family, but ruling families often made closely consanguineous marriages. Plato, in the Laws, prohibited sexual intercourse between full brothers and sisters, and parent and child $(838 \mathrm{a}-\mathrm{c})$, and Xenophon claims that it is one of the unwritten laws that children do not have sex with their parents (Mem. 4.4.19-23). Yet, unlike at Rome, relationships between aunt and nephew (for instance), or half-brother and half-sister were legally possible. ${ }^{22}$ At Corinth, Herodotus says that in the seventh century the ruling Bacchiads intermarried (5.92 $\beta .1)$. At Sparta, the first wife of the Agiad Anaxandrides was his niece (the daughter of his sister: Hdt. 5.39.1), and Gorgo, the daughter of Cleomenes (Hdt. 5.48), married her father's half-brother Leonidas, who became basileus on Cleomenes' death (Hdt. 7.239.4).

\footnotetext{
${ }^{20}$ There is considerable discussion about Polyzalus' position, and much hangs on the inscription (and reinscription) on the base of the Delphic Charioteer. Some have argued (e.g. G. Adornato, 'Delphic enigmas? The Gelas anassōn, Polyzalos, and the Charioteer statue', $A J A$ 112 [2008], 29-55) that the original inscription cannot have been made by Polyzalus, and that he may have been a military commander, but not ruler in Gela. Adornato builds upon the work of C. Rolley, 'En regardant l'aurige', BCH 114 (1990), 285-97; cf. M. Scott, Delphi and Olympia. The Spatial Politics of Panhellenism in the Archaic and Classical Periods (Cambridge, 2010), 89-90 with n. 76. Others (most recently D. Bonano, Ierone il Dinomenide. Storia e rappresentazione [Pisa and Rome, 2010], 56-61) argue that Polyzalus had been ruler in Gela but that, after he went into exile at the Emmenid court and the balance of power between the brothers changed, Hieron altered the inscription to fit his own propagandist needs in Sicily.

${ }^{21}$ D. Asheri, 'Sicily, 478-431 B.C.', CAH v ${ }^{2} 149$; P.J. Rhodes, History of the Classical Greek World, 478-323 B.C. (Oxford, 2005), 71-4; S. Hornblower, The Greek World, 479-323 BC (Abingdon and New York, 20114), 49-51.

${ }^{22}$ R. Just, Women in Athenian Law and Life (London and New York, 1989), 76-9; cf. S. Pomeroy, Goddesses, Whores, Wives and Slaves (New York, 1975), 64. See also S.C. Humphreys, 'The discourse of law in archaic and classical Greece', Law and History Review 6 (1988), 47981. On the legal position regarding consanguineous marriages at Rome, see J.E. Grubbs, Woman and the Law in the Roman Empire (London, 2002), 137-8.
} 
The Eurypontid Leotychides married his daughter Lampito to his grandson (so her nephew: Hdt. 6.71). In Sicily, Dionysius I of Syracuse married one of his seven daughters, Arete, to his brother and right-hand-man Thearides (cf. Diod. Sic. 14.102.3, 103.2-3, 109.2), and when Thearides died she was married to Dion, the brother of Dionysius' Syracusan wife and her natural uncle (Plut. Dion 4.1, 6.1). Another daughter, Sophrosyne, was married to her half-brother (who was to become Dionysius II).

Such close marriage connections were desirable in order to limit and tighten the bonds between the power-sharing group. Dionysius I (in addition to the two later wives) also married the daughter of Hermocrates, the Syracusan general and hero of the Athenian attack of 415-413, though she died in the cavalry revolt early in his rule (Diod. Sic. 13.112.4, 14.44.5), and married his sister to Hermocrates' brother Polyxenus (Diod. Sic. 13.96.3; cf. RO no. 10). As a result of close intrafamilial marriages, many communities were effectively ruled by closed oligarchies based on family connections, such as the Bacchiads (and then the Cypselids) in Corinth or the Aleuads in Thessaly, even if these family groupings were dominated by one male figure. This is the model that Carney has importantly identified for Macedon (so that basileia, or rule, becomes the shared responsibility of the whole family, including the women), but it is a general pattern that recurs around the Greek world in the Archaic and Classical periods. For example, as we have seen, Dionysius I of Syracuse bound his family together in this way, and different members of the extended family bore significant responsibilities within that rule, including Polyxenus and Dion, the brother of Aristomache, Dionysius' Syracusan wife, and husband of Dionysius' daughter.

Among other ruling families (and perhaps also more widely in Greek communities) polygamy also seems to have been common. ${ }^{23}$ We have already noted Philip II's polygamous marriages; his father also had two wives (Justin 7.4.5). ${ }^{24}$ In the early fifth century Hieron of Syracuse had three wives: one was the daughter of a Syracusan, the second the daughter of Anaxilas, the ruler of Rhegium, and the third the niece of Theron, ruler of Acragas (Timaeus, FGrH 566 F 97). At the end of the fifth century, Dionysius I of Syracuse certainly had two wives concurrently (Diod. Sic. 14.44.5-8; Plut. Dion 21.4; cf. Diod. Sic. 13.96.3), whom he married on the same day. The first of these was Doris, the daughter of the most distinguished citizen of Locri, and the assembly of the Locrians (significantly) had voted on the connection. Her son became Dionysius II. His second wife Aristomache was a Syracusan. The Molossian ruling family may also have been polygamous. In the mid-fourth century the Molossian Neoptolemus and his brother Arybbas quarrelled over the succession, and eventually ruled jointly. One way of understanding their disagreement may be to assume that Neoptolemus and Arybbas were half-brothers in a polygamous family, and that it was not clear to which brother rule should pass. ${ }^{25}$

Such difficulties in polygamous families were common, and there was always the potential for conflict and faction, especially in the battle for succession between the children of different wives, and not least between the mothers whose status depended on their children. Certainly Olympias and Alexander clearly felt they

${ }^{23}$ D. Ogden, Polygamy, Prostitutes and Death. The Hellenistic Dynasties (London and Swansea, 1999), xxvi-xxx.

${ }^{24}$ On polygamy among the Macedonian Argeads: W. Greenwalt, 'Polygamy and succession in Argead Macedonia’, Arethusa 22 (1989), 19-45; cf. Carney (n. 11), 23-7.

${ }^{25}$ Cf. Ogden (n. 23), x. 
had been put under pressure by Philip II's last marriage to Cleopatra, and with good reason, since Attalus her uncle was an important and influential member of Philip's court, who was happy to antagonize Alexander, and play on the strained relationship that had developed between Philip and his son (cf. Plut. Alex. 9.6-11).

This was not just an issue at the Macedonian court. The sons of the Spartan Anaxandrides by his two wives also disagreed over who had the greater right to rule. His first wife, who had been childless, fell pregnant after he married his second wife, who also bore him a son, Cleomenes. Cleomenes was the elder of the two but, even though Spartan custom was for the eldest son to rule (Hdt. 5.42.2), Dorieus (the eldest son of the first wife - she had at least three sons) was sure he would succeed his father both because of his andragathia, his 'manly courage', and the fact that he was the 'first' (prōtos) among his peers (the significance of his claims should become apparent below), while Cleomenes (it was said) was not mentally stable and was on the verge of madness (Hdt. 5.42.2; cf. 39.1). ${ }^{26}$ On their father's death, Cleomenes as eldest succeeded to the basileia, and so Dorieus left Sparta bent on founding a colony (although he and most of his companions died in Sicily: Hdt. 5.42.2-46.1).

Taking matters into her own hands, Thebe, the wife of the fourth-century Alexander of Pherae (who controlled all Thessaly through the tageia which Jason of Pherae had reinvented as personal rule in the middle of the fourth century: Xen. Hell. 6.4.34), ${ }^{27}$ planned her husband's murder (Xen. Hell. 6.4.35-7; Diod. Sic. 16.14.1; Plut. Pel. 35.5-12).$^{28}$ Xenophon says there were possibly two motives for her actions: either that Alexander had killed his young lover whom he had imprisoned (who may have been Thebe's brother: cf. Plut. Pel. 28.10), ${ }^{29}$ or that, because Thebe was childless (Xen. Hell. 6.4.37), he was planning to put her away

${ }^{26}$ On Dorieus, see S. Hornblower, 'The Dorieus episode and the Ionian Revolt (5.42-8)', in E. Irwin and E. Greenwood (edd.), Reading Herodotus. A Study of the Logoi in Herodotus' Histories (Cambridge, 2007), 168-78. Hornblower notices, but dismisses too easily, the oddity of Dorieus' claim to kingship based on his andragathia, 'manliness'.

${ }^{27}$ On the Jason and the tageia, see S. Sprawski, Jason of Pherae. A Study on the History of Thessaly in the Years 431-370 B.C. (Krakow, 1999), 23; id., 'Alexander of Pherae: Infelix tyrant', in Lewis (n. 7), 138-9. On the tageia and its relationship to the Thessalian archonship, see B. Helly, L'état Thessalien. Aleuas le Roux, les tetrades et les tagoi (Lyon, 1995), 13-68, 329-58 with M. Sordi, 'I tagoi tessali come suprema magistratura militare del koinon tessalico', Topoi 7 (1997), 177-82; Rhodes and Osborne (n. 9), 222-5.

${ }_{28}$ Although the deed was performed by her brothers, Xenophon says that Thebe not only got rid of his sword when Alexander came home drunk but, when her brothers hesitated, she told them to get on with the job or she would wake him up; she then shut the door and held it shut till he was dead. Plutarch's account is more dramatic and detailed (including a dog that might bark and wool laid on the stairs to cover the sound of her brother's footsteps), although the essential points are the same. In the reaction of the historiographical tradition we have evidence for how Thebe's activities were perceived. That Xenophon omits Thebe's name (though Diodorus knows it, which probably means Ephorus knew it), just as he also knows but chooses not to spell out her relationship to Jason and her murdered brother, but includes some colour in the story (especially that 'she dragged the door shut and held on to the knocker till her husband was dead'), suggests how uncomfortable but how fascinated he is by her and by her actions, just as Plutarch's elaborations tell a similar story.

${ }^{29}$ Homosexual relations among extended family were not unknown, and are not at all surprising (Philip of Macedon was thought to have taken Olympias' brother Alexander as a lover: Justin 8.6.5-6; see also Carney [n. 12], 28-9), but Alexander of Pherae's crimes were multiplied if he had also loved, and then murdered, Thebe's brother, and given her added reason to feel vulnerable and isolated at court. 
and marry the wife of his predecessor Jason (who was also probably his uncle: cf. Plut. Pel. 29.8).

The plot, however, thickens (and certainly darkens) since, as Daniel Ogden has pointed out, Thebe and her brothers were also the children of Jason of Pherae (Plut. Pel. 28.5), and so Thebe may also have felt aggrieved that she was being supplanted by a woman who (as another of Jason's wives) must have been a rival for Thebe's mother in her father's house. ${ }^{30}$ In fact, Thebe may also have been motivated to act because of rivalries over the tageia itself. On his death Jason was succeeded by his brothers Polyphron and Polydorus (Xen. Hell. 6.4.33), though Polydorus was later assassinated by Polyphron. Alexander himself was the nephew of Polyphron (so the son of either Jason or Polydorus: Plut. Pel. 29.8). Thebe and Alexander were probably cousins. It is just conceivable that they may have been half-brother and sister, though it is unlikely that Alexander was preparing to marry one of his father's wives (but not impossible - otherwise she was Alexander's uncle's wife). In any case, Thebe's brothers were rivals with Alexander for the succession (they were all sons of tagoi) and had an equal right to rule. Nevertheless, while Thebe planned the murder, her brothers apparently reaped the rewards. Alexander was succeeded in the tageia by Thebe's brothers, Tisiphonus and Lycophron, who seem to have held the position jointly, though with Tisiphonus as the senior partner (Xen. Hell. 6.4.37; Diod. Sic. 16.14.1, 37.3). ${ }^{31}$

Multiple marriages could cause competition within the family, but other marriages could bring different factions together. It is interesting that the disputed succession in Molossia between Neoptolemus and Arybbas was finalized with the marriage of Neoptolemus' daughter Troas to her uncle Arybbas. The marriage sealed the relationship and secured the cessation of conflict between Neoptolemus and Arybbas (who then ruled jointly), just as the end of extrafamilial conflicts could also be marked by marriage, such as the marriage between Hieron of Syracuse and the daughter of Anaxilas the ruler of Rhegium, or that of the sister of the Macedonian Perdiccas to the Thracian Seuthes, nephew of the king, in the 420s to subvert the impending Thracian attack on Macedon (Thuc. 2.101.5-6).

It is significant that family factions formed around women, and they could become the lynchpin that held together the courts of rulers, or the break-point where they fell apart. In the power struggles that followed Dionysius I's death (which eventually saw Dionysius II ousted by Dion), Aristomache became a key player. Not only was she the mother of potential rival interests to Dionysius II (Plut. Dion 7.2, 14.1), though one of her daughters was also married to him, but also, as the sister of Dion and mother of Dion's wife Arete (Plut. Dion 6.1), she became instrumental in creating Dion's court after he returned to Syracuse from exile (Plut. Dion 51.1-5). It is an indication of Aristomache's importance that, after Dion's own assassination, she and Arete (with Dion's baby son) were also promptly assassinated (Plut. Dion 58.8-9). Aristomache, a central figure in Dionysius' court holding two potentially rival factions together (as mother of the wife of Dionysius' heir and sister of Dion), also became the point at which the court of Dion broke from its alliance with the household of Dionysius to form its own ruling unit.

\footnotetext{
${ }^{30}$ Ogden (n. 23), xxix-xxx.

${ }^{31}$ It is possible they had to be elected to the position, as had Jason and possibly also his successors, including Alexander: see Sprawski (n. 27 [2006]), 139.
} 


\section{WOMEN AND POLITICS IN THE WIDER WORLD}

Although no title was used to designate women of ruling houses (this has sometimes been taken to indicate their lack of importance), ${ }^{32}$ these women could have political influence outside their immediate households. Herodotus tells the story of Gorgo, the eight- or nine-year-old daughter of the Spartan Cleomenes, who was present when her father was supplicated by the Milesian Aristagoras to press for support in the Ionian revolt, and who famously warned her father to throw the Milesian out lest Cleomenes be ruined (Hdt. 5.51). Whether the story itself is true, Gorgo's precociousness seems to have a struck a chord which made it a story worth telling about the Spartan court, but also suggests it was not unusual for women to be part of the welcoming party for visiting dignitaries and suppliants, and the political discussions of the court.

Nevertheless, women who became actively involved with the business of war did not receive such good press $^{33}$ since, as Homer's Hector pointed out to Andromache, as he bade her go to her loom and distaff, war was men's work (Hom. Il. 6.4903). ${ }^{34}$ In sixth-century Cyrene Pheretime, the mother of Arcesilas III (probably the daughter of Battus II, so her husband's great-aunt), ${ }^{35}$ was also a politically capable woman, and acted for her son when he had to travel to nearby Barce, even presiding, Herodotus says, on the Cyrenean council (Hdt. 4.165.1). ${ }^{36}$ However, after a period of civil war in Cyrene, when Arcesilas was forced into exile, Pheretime (according to Herodotus) went to Cyprus to the court of Euelthon of Salamis to ask for an army (Hdt. 4.162.2-5). Euelthon, Herodotus says, gave her (presumably as guest-gifts) everything except the army she wanted. Nevertheless, Herodotus says that each time she received a gift she said it was lovely (kalos) but that an army would be nicer (kallion). Finally Euelthon sent her a golden spindle and distaff with wool on it (surely a deliberately Homeric gift), ${ }^{37}$ and when Pheretime gave her now customary response, Euelthon replied that his gift was suitable for a woman, but soldiers were not.

Even if Herodotus is modelling the facts of the story around the Homeric prototype, Euelthon's gift is repressive and telling. According to the Cypriot's (or at least Herodotus') understanding of female roles, Pheretime was behaving not in a womanly way in asking for a guest-gift which was inappropriate for her gender even though it suited her need. Euelthon's response showed that he thought that women (even ruling women) belonged in the home, and their responsibilities and

${ }^{32}$ Cf. M. Dillon, Girls and Women in Classical Greek Religion (London and New York, 2001), 18-19.

${ }^{33}$ A. Chaniotis, War in the Hellenistic World (Oxford, 2005), 103 suggests that, apart from 'a few notable exceptions, women are almost absent in Hellenistic historiography in connection with war'.

${ }^{34}$ Cf. F. Graf, 'Women, war and warlike divinities', ZPE 55 (1984), 245-54.

${ }^{35}$ Cf. B. Mitchell, 'Cyrene: typical or atypical?', in R. Brock and S. Hodkinson (edd.), Alternatives to Athens. Varieties of Political Organization and Community in Ancient Greece (Oxford, 2000), 92; see also A. Corcella ('Book IV', in D. Asheri, A.B. Lloyd and A. Corcella [edd.], A Commentary on Herodotus Books I-IV [Oxford, 2007], 721), who suggests Herodotus' Battou may be a genitive of possession (rather than a patronymic), and so may simply indicate that Pheretime was the wife of Battus III.

${ }^{36}$ On Pheretime, and women in general in Herodotus, see C. Dewald, 'Biology and politics: women in Herodotus' Histories', Pacific Coast Philology, 15 (1980), 11-18.

${ }^{37}$ On gifts for women, and gifts given by women, see D. Lyons, 'Dangerous gifts: ideologies of marriage and exchange in ancient Greece', ClAnt 22 (2003), 93-134. 
requirements were constrained by that. On the other hand Pheretime, strikingly, even if the story is framed by fifth-century rather than Archaic norms, was not limited by such social expectations, and felt herself able to ask for this normatively unsuitable gift, even if Euelthon, because of his prejudices (and possibly also his foreign policy), was not able to give it. ${ }^{38}$

Pheretime's later career confirmed that she was prepared to push at the boundaries of acceptable behaviour, and, like Olympias, was a witch-like and liminal character. ${ }^{39}$ Fortunately for her son, Arcesilas was restored to his position in Cyrene with the support of the Samians (Hdt. 4.164.1). However, forced to flee Cyrene again, he was assassinated in Barce along with Alazeir, his father-in-law and the local ruler (Hdt. 4.164.2-4). Pheretime wanted revenge, and so went to the Persian satrap in Egypt, who did give her the army she wanted (Hdt. 4.165.2-3); Herodotus says in another story about gifts for women that an army is a very Persian gift (Hdt. 9.109.3). ${ }^{40}$ With this army, Pheretime saw the town of Barce captured, and the assassins were handed over to her for punishment (Hdt. 4.200-2). She impaled the men on spikes in a circle around the city (behaviour elsewhere associated with barbarity, if not exclusively barbarians: Hdt. 9.78-9), ${ }^{41}$ and then cut off their wives' breasts, and put them up as well, giving the assassins' actions (and her punishment) a sexual twist by mutilating their wives, almost as if she herself had been sexually betrayed (Amestris' revenge for Xerxes' infidelity was the mutilation of Masistes' wife, although she herself had been innocent, Hdt. 9.110-13). Likewise, Pheretime was prepared to act on her own and act decisively, forcefully and brutally. ${ }^{42}$ Nevertheless, although a story about the Archaic period, Pheretime's story is a patchwork of fifth-century storytelling and sixth-century events, and Herdotus' telling of it probably tells us more about fifth-century attitudes to how women should behave (and how they should be detached from war) than those of the Archaic period.

${ }^{38}$ Indeed, even if the details of the Herodotean story are created out of fifth-century prejudices, the fact that Euelthon did not help her chimes true against the value systems encouraged by Homeric epic.

${ }^{39}$ Herodotus says that Pheretime did not come to a happy end, but herself died a terrible death on her return to Egypt. She was infested with worms while still alive, as happens to mortals, Herodotus says, since excessive revenge causes the gods to become jealous (Hdt. 4.205). On the 'double determination' of Pheretime's fate - by the gods and by nature - see G.E.R. Lloyd, Magic, Reason and Experience. Studies in the Origin and Development of Greek Science (London, New York and Melbourne, 1979), 31-2 with n. 108. For the moralizing possibilities of phthiriasis (corruption of the body by lice or maggots), see T. Africa, 'Worms and the death of kings: a cautionary note on disease and history', ClAnt 1 (1982), 1-17. Note also W.R. Dawson with notes by F.D. Harvey, 'Herodotus as a medical writer', BICS 33 (1986), 95 n. 43. It is also significant that for Herodotus Pheretime's crime is one against the gods, which did not recognize that she was overstepping her mortal limits (see D. Asheri, 'General introduction', in Asheri, Lloyd and Corcella [n. 35], 38-9), rather than the apparent barbarity and unwomanliness of her actions.

${ }^{40}$ Xerxes offered an army to the daughter of Masistes to prevent her betraying their adultery to his wife - which suggests that there was more at stake in this affair than Herodotus allows: cf. H. Sancisi-Weerdenburg, 'Exit Atossa: images of women in Greek historiography on Persia', in A. Cameron and A. Kuhrt (edd.), Images of Women in Antiquity (London and Canberra, 1983), 28-30.

${ }^{41}$ Impalement of the dead seems to have been problematic (cf. Hdt. 4.202.1 with 205), although crucifixion of the living was acceptable (cf. Hdt. 9.120.4). See also M. Flower, 'Herodotus and Persia', in C. Dewald and J. Marincola (edd.), The Cambridge Companion to Herodotus (New York, 2006), 286, although Herodotus is less positive about Xanthippus' activities.

${ }^{42}$ On Persian women in Herodotus, see Sancisi-Weerdenburg (n. 40), 20-33. 
There are other women who act, according to Greek norms, in this 'manly' or perverted way. Artemisia of Halicarnassus (another Herodotean woman) held the tyranny after her husband's death, even though she had a son, and went to war as part of Xerxes' army 'because of her drive (lēma) and manly courage (andrēiēe', not because she was compelled to (Hdt. 7.99.1). When Artemisia escaped after Salamis, Herodotus says that the Athenians had offered a reward of 1000 drachmas for her capture alive, as the Athenians thought it a terrible thing for a woman to march to war against them (8.93). ${ }^{43}$ In the same way, in the fourth century, Mania of Dardanus, who had taken over the 'satrapy' of Aeolis after her husband's death, ${ }^{44}$ was strangled by her son-in-law, who was put out that people were saying it was a disgrace that a woman should rule and for him to be an idiōtēs, a private citizen (Xen. Hell. 3.1.10-14).

Mary Lefkowitz has argued that even the apparently politically independent Hellenistic queens only ever actually acted through male consorts ${ }^{45}$ but at least in Archaic and Classical Greece the picture is not as simple as this. It may be argued that Artemisia and Mania were ruling in the context of the Persian empire (where women such as the fourth-century Artemisia and Ada of Caria could rule), but both Herodotus' Artemisia and Mania were ruling Greek cities. Even if Herodotus' reactions to Artemisia and Pheretime belong in the fifth century, their stories together with Mania's show that women in Greek communities, even in the Archaic and Classical periods, did rule independently. However, it is also quite clear that at least from a fifth- and fourth-century perspective their position could be difficult and even dangerous, as they were acting in ways that society thought they should not, and by doing so they themselves became liminal and even threatening.

However, there were political activities appropriate to women and, as Lefkowitz has suggested, women could play a socially acceptable role in the 'softer' side of ruling. ${ }^{46}$ For instance, Dionysius of Syracuse used his daughters to make quasireligious (or at least politically ethical) statements about the nature of his rule. Elected as general with sole and full powers in 405 B.c. and styling himself archōn of Sicily, ${ }^{47}$ Dionysius became in the fourth century a paradigmatic tyrant who was coupled by Lysias with the Persian King (against both of whom Lysias urged a barbarian war in a speech delivered at the Olympic Games probably of 384 B.C.: Lys. 33). ${ }^{48}$ Dionysius, however, was keen to represent his rule in a more positive light. Not only did he write poetry in which he decried tyranny (saying that it was the mother of injustice: $T G F$ fr. 4 Snell), but also he named three of his daughters Arete, Dicaeosyne and Sophrosyne (Plut. De Alex. fort. 5.338c, Dion 6.1), which, as

${ }^{43}$ Xerxes himself praised Artemisia on her activities at Salamis saying: 'My men have become women, and my women men' (Hdt. 8.88.3). For the ironic oppositions in Herodotus' treatment of Artemisia, see R.V. Munson, 'Artemisia in Herodotus', ClAnt 7 (1988), 91-106. Note also J. Romm, Herodotus (New Haven and London, 1998), 171-2.

${ }^{44}$ Xenophon says that Mania's husband Zenis held the 'satrapy' of Aeolis for Pharnabazus, by which he must mean that Zenis had control of the region of Aeolis. Xenophon, a little later, suggests that Mania was behaving like a tyrannos (Hell. 3.1.14).

${ }_{45}^{4}$ M. Lefkowitz, 'Influential women', in Cameron and Kuhrt (n. 40), 49-64.

${ }^{46}$ Ibid. 61.

${ }^{47}$ See n. 9 above.

${ }^{48}$ For the date: G. Grote, A History of Greece; From the Earliest Period to the Close of the Generation Contemporary with Alexander the Great, new ed., 12 vols (London, 1869), 9.291-2 n. 3, 10.312-13 n. 1; D.M. Lewis, 'Sicily, 413-368 в.C.', in $C A H$ vi $^{2}, 139$ n. 82 is inclined to accept this date, although Diodorus gives a date of 388 в.c. which is accepted by Ostwald, 'The growth of schools and the advance of knowledge', $C A H \mathrm{vi}^{2}, 598$. 
Sanders notes, was self-consciously buying into fourth-century political theorizing on the virtues that a basileus should espouse (e.g. Xen. Cyr. 1.2.6-8, 6.21-2; Isoc., Nic. 12, Ad Nic. 38; Euag. 23-4; note also Xen. Ages. 4.3-8, An. 1.9). ${ }^{49}$ In this way Dionysius' daughters became political and ethical symbols (since in the early fourth century virtue, justice and moderation all had ethical value) for his rule. ${ }^{50}$ Further, as 'father' of political virtues, Dionysius seems to be drawing a parallel between himself and Zeus (who was father of Eunomia, Dike and Eirene: Hes. Theog. 901), suggesting that his rule not only represented but was even the source of these virtues, which his daughters both represented (as a statement about his rule), and to which they also gave a physical and living substance. In this sense they were intrinsic to his rule, because of the symbolic value they added to it.

Women apparently could also play an active diplomatic role. Still in Sicily Demarete, the wife of Gelon, was involved in the peace negotiations with the Carthaginians after their defeat at the battle of Himera in 480 B.c. and bargained on their behalf, achieving for them very favourable terms (Diod. Sic. 11.26.2-3).$^{51}$ As a result of her diplomatic success, the Carthaginians rewarded her with a gold crown of one hundred talents. Diodorus says that she struck a series of coins from the crown given her by the Carthaginians, the Demareteion, though the earliest (silver) decadrachm from Sicily dates to about twenty years later, ${ }^{52}$ raising doubts that this could be Demarete's issue, and the so-called Demareteion is often now associated with the fall of tyranny in the 460s. Nevertheless, although he is the chief proponent of the redating of the silver decadrachm, Kraay still believes that there was an issue in 480 in honour of Demarete, but that it was a series minted in gold, and now lost to us. ${ }^{53}$ So Demarete was not just involved in politics, but also had an impact on the economic activities and organization of the community.

Furthermore, given the emblematic and symbolic nature of coinage in the ancient world, where coins often bore images which represented the community in abstract terms ${ }^{54}$ the Demareteion (even with a later dating) has greater significance. Its importance would be further heightened if, as Steiber argues, the silver decadrachm bears a 'portrait', which she identifies as Demarete, albeit conflated with an image of Artemis or Arethusa (and admittedly retaining the traditional 480 dating of the silver issue in the face of strong numismatic argument). ${ }^{55}$ Although after Gelon's

\footnotetext{
${ }^{49}$ Sanders (n. 10), 2.

${ }^{50} \mathrm{On}$ the ethical value of dikaiosyne, which had been lacking from dike, in the late fifth century, see E.A. Havelock, "Dikaiosune". An essay in Greek intellectual history', Phoenix 23 (1969), 49-70. That is not to suggest, however, that an ethical understanding of human action as such did not emerge before this period. Christopher Gill argues that from the Homeric period ethical reasoning and individual choices were driven by the idea of the good in communal terms, just as the consequences of individual actions were shared by the community and shaped by the participation of the individual in the community; see C. Gill, Personality in Greek Epic, Tragedy, and Philosophy: The Self in Dialogue (Oxford, 1996).

${ }^{51}$ Late sources also say Demarete used her personal jewellery to help fund Gelon's war effort (Pollux 9.85).

${ }^{52}$ It is now generally accepted that this series must date to the mid-460s; see e.g. C.M. Kraay, Greek Coins and History (London, 1969), 19-42; id. Archaic and Classical Greek Coins (London, 1976), 205-6, 211; I. Carradice and M.J. Price, Coinage in the Greek World (London, 1988), 17, 44-5; H.B. Mattingly, 'The Demareteion controversy - a new approach', Chiron 22 (1992), 1-11.

${ }^{53}$ Kraay (n. 52 [1969]).

${ }^{54}$ See C. Howgego, Ancient History from Coins (London and New York, 1995), 62-7.

${ }_{55}$ M. Steiber, The Poetics of Appearance in the Attic Korai (Austin, 2004), 101-3.
} 
death Demarete was married to his brother (who was ruler in Gela), she was buried at Syracuse with Gelon in considerable state (Diod. Sic. 14.63.3). Clearly she retained a strong symbolic connection with Syracuse, and it is conceivable that Demarete may have received some form of hero cult, ${ }^{56}$ as Gelon did when he died (Diod. Sic. 11.38.5), and that the coin was issued, possibly by Hieron (who succeeded Gelon at Syracuse), to commemorate her death, and to emphasize his connection with Gelon's house. ${ }^{57}$ The figure on the coin certainly has a corona which is not used on the Artemis/Arethusa type. ${ }^{58}$ The 'mixing' of Demarete's image with that of the goddess or nymph may thus be similar to Alexander's portraits on his issue of silver tetradrachms which appear to be 'mixed' with Heracles, suggesting a comparison with the hero-god..$^{59}$ Demarete, then, in some sense would have become not only the 'face' of Syracuse, but also would have represented in this heroized, almost semi-divine conflation, the heroic rule of Gelon and his heirs at a time when portraits (at least of male rulers) on coins were unknown. ${ }^{60}$ The difficulty with such an interpretation is that it would appear to separate the coins from the reward given to Demarete, although this is not impossible if the crown was used to fund the issue, even at Demarete's death.

However, whether or not the silver decadrachm is the Demareteion, and whether or not it bears a portrait of Demarete, ${ }^{61}$ that her reward was conferred on the city in this way would have meant that Gelon's wife had a continuing, tangible and potent presence within the city. Further, by turning the personal reward of the gold crown into the explicitly civic medium of coins, Demarete's honour was shared with the whole community of the Syracusans, and it was made clear both that her diplomatic activities were enacted on behalf of the whole community and that the city itself shared in the original benefaction and the honours that thereby accrued.

\footnotetext{
${ }^{56}$ It is conceivable that Demarete was given cult at the same time as Gelon, since it seems wives could achieve heroic status together with their husbands. As Emily Kearns notes, on the 'Totenmahl' reliefs (which date from the sixth century into the Hellenistic period) heroes are attended by women of the same type (heroines) but of lesser status; see E. Kearns, 'The nature of heroines', in S. Blundell and M. Williamson (edd.), The Sacred and the Feminine in Ancient Greece (London and New York, 1998), 98-9. On the Totenmahl reliefs, which were specifically intended to honour heroes, both local heroes and the recently dead on whom heroic status had been confirmed (rather than the ordinary dead), see J.L. Larson, Greek Heroine Cults (Madison, 1995), 45-50 (who also comments on the possibility of wives sharing the heroic elevation of their husbands).

${ }^{57}$ Gelon seems to have had strong popular support for his rule (Diod. Sic. 11.22.1 [cf. 13.95.1], 26.5-6, 14.66.1; but cf. the hostile account at Hdt. 7.154-5), and was possibly acclaimed as benefactor (euergetès), saviour (sōtèr) and basileus (B. Currie, Pindar and the Cult of Heroes [Oxford, 2005], 170 defends these titles as honours already known in Pindar, though Hornblower [n. 21, 47-8] must be right that they are an anachronism, belonging properly to the Hellenistic world). Dionysius I later tried to make connections with the earlier ruler in order to bolster his own position in Syracuse (Diod. Sic. 13.95.1-3).

${ }^{58} \mathrm{My}$ thanks to Professor Barbara Borg for pointing this out to me.

${ }^{59}$ A.R. Bellinger, Essays on the Coinage of Alexander the Great, Numismatic Studies no. 11 (New York, 1963), 13-21.

${ }^{60}$ Howgego (n. 54), 63-7.

${ }^{61}$ It is also possible, however, that the link between the coin and Demarete is a false one. Williams suggests that the actual namesake of the coin is Demeter (R.T. Williams, 'The Demareteion reconsidered', $N C 12$ [1972], 10-11 is happy with a date in the 470s but not the 460s), though Diodorus (and his source - probably the fourth-century Sicilian historian, Timaeus: L. Pearson, 'Ephorus and Timaeus in Diodorus. Laqueur's thesis rejected', Historia 33 [1984], 1-20) believed in it.
} 


\section{WOMEN AND HEROISM IN RULING FAMILIES}

As we have seen, the women of ruling families played an active role in the political life of the community. In order to do this, these women had to imagine themselves and their place in the community differently from other women. In this it appears they were enabled by their share in the heroic nature of ruling, although to become truly heroic also placed them in a difficult position in regard to the community.

The conjunction between heroic stature and ruling was fundamental, and most rulers saw themselves as imbued with heroic qualities because of their descent from heroic ancestors. The right to rule was thought in part to derive from heroic ancestry on the grounds that those born from heroes also succeeded to the original heroic virtues. Pindar (Pyth. 5.96-8) says that even the descendants of Battus, the founder-basileus of Cyrene, were also 'sacred' (though there is some debate as to whether they, like Battus I as oecist, also received cult: Pind. Pyth. 5.94-5). ${ }^{62}$ The Spartan kings received hero cult on their death (Xen. Lac. Pol. 15.9), as did Gelon at Syracuse and Theron at Acragas (Diod. Sic. 11.38.5, 53.1-2). ${ }^{63}$

Heroic descent of ruling women raised their status, and marriages between family-members who shared heroic descent could ensure that the heroic patrimony was intensified. The Molossian royal family claimed descent from Achilles through his son Neoptolemus, ${ }^{64}$ but the story had taken firm hold by the fifth century (Pindar says in the seventh Nemean that Neoptolemus ruled there for a short time: 34-40; cf. Nem. 4.51-3; Paean 6.98-121). It was further elaborated by Euripides who made the Molossians also descendants of Andromache through Molossus, her son by Neoptolemus (Andr. 1243-6). Other traditions also say Andromache later married Helenus, the son of Priam (Paus. 1.11.1-2, 2.23.6). Olympias also claimed him as her ancestor (Theopompus, FGrH $115 \mathrm{~F} 355$ ), and Carney has argued that Olympias was well aware of her lineage, and actively sought to live the life of a heroine, using as her models the heroines of drama. ${ }^{65}$

${ }^{62}$ See Currie (n. 57), 236-44, 246-7, though J.F. McGlew (Tyranny and Political Culture in Ancient Greece [Cambridge, 1993], 173) thinks it unlikely that Battus' descendants also received cult. There is currently an important debate being aired in regard to the existence and significance of oikistai. Robin Osborne argues for a new model for colonization which sees the process not as systematic but as diffuse and continuing over an extended period: 'Early Greek colonization? The nature of early Greek settlement in the West', in Fisher and van Wees (n. 8), 251-69; see also Osborne (n. 2), esp. 8-15, 110-23. The case for city foundations and founders has been put strongly by Irad Malkin: "Exploring the validity of the concept of "foundation": a visit to Megara Hyblaea', in V.B. Gorman and E.W. Robinson (edd.), Oikistes. Studies in Constitutions, Colonies and Military Power in the Ancient World offered in Honor of A.J. Graham (Leiden, 2002), 195-225; “"Tradition” in Herodotus: the foundation of Cyrene', in P.S. Derow and R.C.T. Parker (edd.), Herodotus and his World: Essays from a Conference in Memory of George Forrest (Oxford, 2003), 153-70; and 'Networks and the emergence of Greek identity', in I. Malkin (ed.), Mediterranean Paradigms and Classical Antiquity (London and New York, 2005), esp. 66-71; 'Foundations', in Raaflaub and van Wees (n. 2), 373-94 (which presents more of a compromise position).

${ }^{63}$ Cf. T. Fischer-Hansen, T.H. Nielsen and C. Ampolo, 'Sikelia', in M.H. Hansen and T.H. Nielsen (edd.), An Inventory of Archaic and Classical Poleis (Oxford, 2004) 187.

${ }^{64}$ This story first seems to have been circulated in the seventh century when Neoptolemus was said to have visited Achilles' father in Epirus on his way home from Troy (Hagias of Troezen ap. Proclus, Chrestomathia).

${ }^{65}$ Carney (n. 11), 6. William Allan has suggested that Euripides' Andromache was produced, if not originally for a Molossian audience, then with a performance in Molossia in view; see W. Allan, The Andromache and Euripidean Tragedy (Oxford, 2000), 152-8. Achilles 
Rulers became heroes because they were born from heroes, ${ }^{66}$ but also because they did heroic things. ${ }^{67}$ Not only was one of the primary functions of a ruler in many Greek states to lead the army in war, ${ }^{68}$ but also their position was legitimated by the fact that they, like heroes, had more arete than anyone else (cf. Arist. Eth. Nic. 7.1145a23-4). ${ }^{69}$ Herodotus in the Constitution Debate has Darius justify rule by one man on the grounds that the monarch is the aristos man, that is the one with the most aretē (3.82.2), and Xenophon has his Cyrus think that his legitimacy must depend on his being the most prudent (Cyr. 1.6.20-23), and most adorned of all with aretē (Cyr. 8.1.21). Euagoras of Salamis, who refounded the dynasty on Cyprus, not only traced his family's descent back to Aeacus, and so to Zeus (Isoc. Euag. 12-18; Nic. 42), but also was honoured with cult for his great deeds (Isoc. Euag. 1-2). Thus the founding of cities could lead to heroic honours (on the grounds that oecists, like lawgivers, or any 'first inventors', were heroes) ${ }^{70}$ just as participation in the crown games was also seen as an activity which was appropriate for those who aspired to heroic status. ${ }^{71}$ For this reason the Spartan Deioces, as the son with the greatest andragathia, thought he had the greater right to rule.

was to become a very important figure in Alexander's life, as was Heracles (from whom the Macedonians claimed descent: e.g., Isoc. 5.32-4, 105; cf. Hdt. 8.137.1), and Alexander's activities and aspirations were shaped by the desire to emulate both his heroic ancestors (see also Mitchell [n. 5 (2007)], 192-3).

${ }^{66}$ Note H. Lloyd-Jones, The Justice of Zeus (Berkeley, Los Angeles and London, 1971), 51.

${ }^{67}$ Currie (n. 57). Note also E. Carney, 'The initiation of cult for royal Macedonian women', CPh 95 (2000), 21-43. For a more cautious position on the relationship between rulers and divinity: S.R.F. Price, 'Gods and emperors: the Greek language of the Roman imperial cult', JHS 104 (1984), 79-95; id., Rituals and Power. The Roman Imperial Cult in Asia Minor (Cambridge, 1984), 23-40; A. Chaniotis, 'The divinity of Hellenistic rulers', in A. Erskine (ed.), A Companion to the Hellenistic World (Oxford, 2003), 431-45; cf. W. Burkert, Greek Religion: Archaic and Classical (tr. J. Raffan; Oxford, 1985; originally published as Griechische Religion der archaischen und klassischen Epoche [Stuttgart, 1977]), 205-8.

${ }^{68}$ Chaniotis (n. 33), 57-77 argues for the importance of war in the ideology of kingship in the Hellenistic period. War was also intrinsic to monarchical ideology in earlier periods. As we have seen, Aristotle disparages basileis, such as those at Sparta, whose principal duty was to lead the army in war, and yet for many early rulers war seems to have been almost a ritual activity.

${ }^{69}$ Cf. G. Nagy, The Best of the Achaeans. Concepts of the Hero in Archaic Greek Poetry (Baltimore and London, 1979), 26-41.

${ }^{70}$ Rulers, who required heroic status, were often also city founders (or refounders), an accomplishment which also proved their heroism even as it created it, forming a tradition that continued into the Hellenistic world (cf. Chaniotis [n. 67], 436): Diodorus says that Hieron in Sicily refounded Catana as Aetna in order that he would receive heroic honours (Diod. Sic. 11.49.1-2); Miltiades, who was appointed tyrant of the Dolonci, was honoured on his death as an oecist (Hdt. 6.38.1); Timoleon, according to Plutarch, was asked to refound Syracuse, and was honoured by them as an oikistēs (Plut. Tim. 23.1, 35.3-4); Isocrates says that the first Spartan kings were also regarded as oikistai (Isoc. 4.61, 65).

${ }^{71}$ The image of the ruler as hero was also strengthened through Panhellenic victories, which could also lead to cult for victors even in their lifetime (B. Currie, 'Euthymos of Locri: a case study in heroization in the classical period', JHS 122 (2002), 22-44; id. [n. 57], 120-57). Hieron of Syracuse won the single-horse race at Olympia in 476 (Pind. Ol. 1; Bacchyl. 5) and in 472 (for this victory, see L. Moretti, Olympionikai. I vincitori negli antichi agoni Olimpici [Rome, 1957], 92 [no. 234]), the chariot race at the Pythian games in 470 (Pindar, Pyth. 1; Bacchyl. 4), and at Olympia in 468 (Bacchyl. 3). Theron of Acragas won the chariot race at Olympia in 476 (Pind. Ol. 2). Arcesilas of Cyrene won an Olympic victory and a Pythian victory (Pind. Pyth. 4, 5, $\Sigma$ Pind. Pyth. 4). Arybbas of Molossia was twice Olympic victor and Delphic victor (RO no. 70). Cylon of Athens was also an Olympic victor, as both Thucydides and Herodotus are careful to point out (Hdt. 5.71.1; Thuc. 1.126.3 - even if for Thucydides the reference also serves to make the connection with Alcibiades and his alleged aspirations). Participation and 
The heroic nature of ruling and the essential heroism of rulers had an impact on their women. Deborah Lyons observes that, in epic, heroines were the wives and mothers of the best men, ${ }^{72}$ and as descendants of heroes, women could also participate actively in their heroic heritage and be empowered by it. One of the best examples is Cynisca, the sister of the Spartan kings Agis II and Agesilaus, who was the first woman to win an Olympic victory with a quadriga (Paus. 3.8.1) - she probably had victories in 396 and 392 B.c. Cynisca was also the first woman to receive hero cult in her own right; there was a heroön built for her near the Platanistas (Paus. 3.15.1), where violent and warlike contests for Spartan ephebes were held (Paus. 3.14.8-10), ${ }^{73}$ and she had a portrait statue (eikōn) erected of herself in the sanctuary at Olympia (Paus. 6.1.6), as well as a statue of the horses in the sanctuary of Olympian Zeus (Paus. 5.12.5). There was also an epigram which read $($ GESA 33 = CEG 820; Anth. Pal. 13.16):



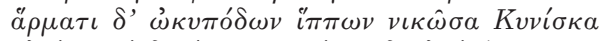

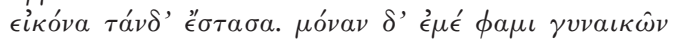

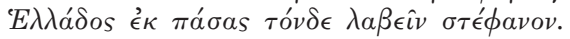

Spartan kings are my fathers and brothers, having won the race with a team of swift-footed horses, I Cynisca put up this monument. I say that I alone of women in all Greece have won this crown.

Cynisca shows her own sense of strength and personal superiority through the strong and exclusive first-person statements: Cynisca herself put up the monument, and 'she' asserts that 'she alone' of women had the won the event. She was probably emulated by Spartan women (Pausanias knew of another Spartan woman who won a chariot victory at Olympia in 368 B.C.: Paus: 3.17 .6$),{ }^{74}$ and in later periods she became a paradigm for royal women in the wider Greek world who were trying to express personal power through participation in the games: $:^{75}$ in an epigram by Posidippus (87 AB) Berenice I (wife of Ptolemy I) is said to have eclipsed Cynisca's victory. ${ }^{76}$ However, Cynisca also seems to have been an exemplum for young men, since the location of her heroön suggests that they were the focus for her cult. ${ }^{77}$

victories in the games were not only important for competitive politics with other members of the local elite as a means of affirming superiority, but also were a demonstration of excellence (in Olympian 1, Pindar says that the horse-loving basileus Hieron 'culls the peaks of every arete, 13), and wealth (Hieron, in Pythian 2, is said to excel everyone else in wealth and in honour, timē, 59-61; cf. Bacchyl. 3). The ability to make a public display of this kind was a mark of one's worth. Miltiades, the tyrant in the Thracian Chersonese had been an Olympic victor before the Dolonci invited him to rule them (Hdt. 6.36.1).

72 D. Lyons, Gender and Immortality. Heroines in Ancient Greek Myth and Cult (Princeton, 1997), 18-20.

${ }^{73}$ Z. Newby, Greek Athletics in the Roman World: Victory and Virtue (Oxford, 2005), 155-6.

${ }^{74}$ M. Golden, Greek Sport and Social Status (Austin, 2009), 11.

${ }^{75}$ M. Fantuzzi and R. Hunter, Tradition and Innovation in Hellenistic Poetry (Cambridge, 2004), 377-403.

${ }^{76}$ Ibid. 395, 397-8.

${ }^{77}$ Compare Emily Kearns' ([n. 56], 96-110) analysis of sex reversal and transitions, such as the ephebic worship of Aglaurus at Athens. 
Cynisca was 'the first' woman to rear and train horses, and the first woman to be an Olympic victor. To be a 'first inventor' on its own was enough to prove her heroism. ${ }^{78}$ But as such a 'first person', in an extraordinary way she was also intruding into a male space that was not only defined by its masculine activities, but also excluded women, who were not allowed to watch the games (Paus. 5.6.7-8; Arist. fr. 569 Rose), let alone participate (though Pausanias seems to say that parthenoi could spectate: 6.20 .9 , cf. 5.13.10).$^{79}$ There is an audacity and subversiveness about the portrait Cynisca erected of herself, giving her a permanent presence, as it were, where her actual physical presence had been prohibited. She could just have had a statue of her horses erected (as indeed she did), but to place a permanent image of herself within the sanctuary was politically charged. Cynisca, then, is breaking traditions on more than one level, and making a statement about her importance not so much irrespective of, but because of her sex. ${ }^{80}$

On her death Cynisca was celebrated as a heroic woman, but not as a heroine. Although Xenophon tells the story that Agesilaus admonished Cynisca for her victories on the grounds that they were the result of wealth, not the manly virtue of andragathia (Ages. 9.6-7; cf. Plut. Ages. 20.1, Apoth. Lac. 212B), ${ }^{81}$ he has his own agenda concerning kingly virtue which he says resided in friendship and benefaction, caring for one's subjects and punishing one's enemies (cf. Xen. Hier. 11.5-12), and Agesilaus represents for him (or at least in his writing) the acme of kingly virtue. In fact, by cutting against the normal valuations of success in the games, Xenophon emphasizes the fact that they were thought to represent (and to express) andragathia, a virtue which was normally associated with men and with war. ${ }^{82}$

Nevertheless, it does seem to be the case that, although ruling women may have lived heroic lives, very few (other than Cynisca, and perhaps Demarete) appear to have received heroic honours before the Hellenistic period, and Demarete may well have received cult (if she did) because Gelon did. The logic of this is simple, however, since the heroic quality of excellence was a masculine one and, as we have seen, women who displayed it were not proper women. Most women, by virtue of their gender, were unable to attain heroic status on their own account, although they may have achieved it through their husbands. It is telling that the Greeks were often rather vague about heroines, ${ }^{83}$ and in the Archaic and Classical periods they are generally figures who do not have a human existence, although, according to one reading of Plutarch's Lycurgus, at Sparta women who died in childbirth, like men who died in war, were hieroi, 'sacred' (Plut. Lyc. 27.3) ${ }^{84}$ Mothers of heroes

${ }^{78}$ In the same way that oecists received hero cult (see n. 70 above).

${ }^{79}$ See M. Dillon, 'Did parthenoi attend the Olympic Games? Girls and women competing, spectating, and carrying out cult roles at Greek religious festivals', Hermes 4 (2000), 457-80.

${ }^{80}$ Donald Kyle, followed by Golden (n. 74), 10-12, reads Cynisca's victories and Agesilaus' role rather differently, arguing that Agesilaus pressured her into competing so that he could use her victories (and her gender) to attack Elis by 'emasculating' the Olympic chariot race; see D.G. Kyle, Sport and Spectacle in the Ancient World (Malden, Oxford and Carlton, 2007), 188-96.

${ }^{81}$ See S. Pomeroy, Spartan Women (Oxford, 2002), 21-4.

${ }^{82}$ See esp. D. Whitehead, 'Andragathia and arete'', in L.G. Mitchell and L. Rubinstein (edd.), Greek History and Epigraphy. Essays in Honour of P.J. Rhodes (Swansea, 2009), 47-58.

${ }_{83}$ Although Lyons has argued that it was a meaningful category: Lyons (n. 72), 7-34.

${ }^{84}$ See Currie (n. 57), 161 for the point that not all herōs are dead humans, but some are 'supernatural beings subordinate to a theos'; 238-9 with n. 83 on Plut. Lyc. 27.3. Currie, on the basis of Latte's original emendation - which had excised $\tau \hat{\omega} \nu$ i $\in \hat{\omega} \hat{\nu}$ and replaced it with $\lambda \epsilon \chi \circ \hat{v} s$ - still inserts $\lambda \epsilon \chi \circ \hat{v}_{S}$ but also retains $\tau \hat{\omega} \nu$ i $\epsilon \rho \hat{\omega} v$ on the basis of M.B. Wallace, 'Notes 
might be heroines, and Philip seems to have been hinting at that with the statues of his mother Eurydice and Olympias, the mother of Alexander, in the Philippeum - though he is only hinting (as he was also with his own status) since (as Carney observes) there is no evidence of divine cult and the Philippeum is not a heroön. ${ }^{85}$

In the Archaic and Classical periods, rulers were heroes and not gods. Even Dionysius of Syracuse did not claim to be divine, although he may have compared himself to Dionysus (Dio. Chrys. 37.21) ${ }^{86}$ and Plutarch says Dionysius II called himself the son of Apollo (De Alex. fort. 5.338B). ${ }^{87}$ By 324, however, Alexander the Great was openly recognized not just as a hero, but as a god. At Athens, he was declared anikêtos theos, 'unconquered god' (Hyp. Dem. 32), so it seems to have been tacitly accepted that, as 'unconquered', his virtue was enough to make him not just hero but also divine - Aristotle in the Politics had conceded that a man with so much more aretē than anyone else to deserve to rule them would be like Zeus (though he also thought no one could be this deserving: Pol. 3, 1284a3-15, $1284 \mathrm{~b} 25-34$, cf. 3, 1287a28-32). ${ }^{88}$

Olympias, then, was mother of a god, but not the wife of one, though she may have let the story be known that she had slept with a god in the form of snake (Plut. Alex. 2.7, 3.2-4). ${ }^{89}$ However, his mother's possible divine dalliance was a more difficult route to deity for Alexander than divinity through excellence, even if he was suggesting that he had dual paternity, since the Macedonians sneered that if he was the son of god then he was not the son of Philip (cf. Arr. Anab. 7.8.3). ${ }^{90}$ Yet few women slept with gods from choice, and of those that did, few survived unscathed..$^{91}$

Alexander's successors were to receive divine honours, as did their wives. The preceding age, however, was for the most part the age not of gods, but of heroes, and not just heroic men but also heroic women, who seem to have been prepared to share in the business of ruling in a very heroic way. Although the picture that

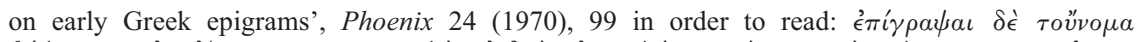

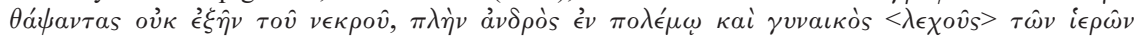
$\alpha \pi \circ \theta \alpha \nu o ́ \nu \tau \omega \nu$. Matthew Dillon, however, sees no need for the original emendation, and thinks

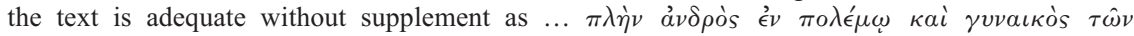
$i \in \rho \hat{\omega} \nu$ a $\pi \circ \theta \alpha \nu o ́ v \tau \omega \nu$ on the basis that it was men in battle and 'priestesses' who have their names inscribed when they die; see M.P.J. Dillon, 'Were Spartan women who died in childbirth

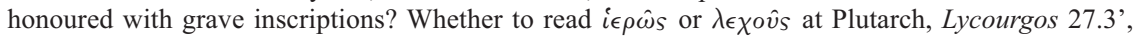
Hermes 135 (2007), 149-65.

${ }^{85}$ Carney (n. 11), 212-13. See also ead. (n. 67), 21-43. Schultz (n. 12), 205-33 argues, however, that the statue group was at the least heroizing or 'divinizing', and that, although there is no evidence of cult, 'the urge to understand the Philippeion's architecture as communicating the idea of heroön is also very strong'.

${ }^{86}$ But see L.J. Sanders, 'Dionysius I of Syracuse and the origins of Greek ruler cult', Historia 40 (1991), 275-87, who argues for the likelihood of ruler cult during Dionysius' lifetime.

${ }^{87}$ Currie (n. 57), 136.

${ }^{88}$ For an analysis of Aristotle's views on the possibilities of pambasileia: W.R. Newell, 'Superlative virtue: the problem of monarchy in Aristotle's Politics', in C. Lord and D. O'Connor (edd.), Essays on the Foundation of Aristotelian Political Science (Berkeley, Los Angeles and Oxford, 1991), 191-211. See also C.A. Bates, Jr., Aristotle's "Best Regime": Kingship, Democracy and the Rule of Law (Baton Rouge, 2003), 183-7.

${ }^{89}$ Cf. P.A. Brunt, Arrian, History of Alexander and Indica (Cambridge, MA and London, 1989), app. V.

${ }^{90}$ It is perhaps significant that on his deathbed, Alexander passed his rule to the kratistos, the best man (Diod. Sic. 17.117.4 [cf. 18.1.4]; Arr. Anab. 7.26.3).

${ }^{91}$ Lyons (n. 72), 99-102. 
we have of domestic seclusion may be more true of Athens than other places inscriptions from Epirus show that at least in fourth-century Molossia alienable citizenship could be conferred on women ${ }^{92}$ - these ruling women, because of their own heroic credentials, did not feel themselves limited by societal norms and expectations, even if they were sometimes feared, vilified, and accused of being barbaric, witch-like and unwomanly, accusations which stemmed from a sense that ruling, and its preoccupation with war, was not a fitting occupation for a woman. As a result, while they had a heroic heritage which provided the intellectual space for them to act in ways most women did not or could not, in doing the work of men their gender became compromised and ambivalent, so that they were neither men nor any longer proper women.

It remains to ask whether it is significant that many of these women come from cities which might, from an Athenocentric point of view, be considered to lie on the edges of the Greek world: Sicily, Thessaly, Macedon, Epirus, Cyrene, Halicarnassus, for example. However, even Athens had rulers in the Archaic period, the Pisistratidae and others, notably Cylon (Hdt. 5.71; Thuc. 1.126.3-11) and Damasias ([Arist.] Ath. Pol. 13.2), who attempted to hold rule; even in the fifth century there were those who had doubts about whether Pericles at the height of his power should be called ruler (or tyrant). Yet there were also rulers in other central regions in both the Archaic and Classical periods. Although Pausanias says that the last king of Argos was deposed by the demos in the mid-sixth century (Paus. 2.19.2), ${ }^{93}$ it seems that there was also an Argive basileus at the beginning of the fifth century who still had responsibility for leading the army in war, and he would have represented the Argives on the war council against the Persians, though the Argives chose not to take part (Hdt. 7.149). Furthermore, in the Classical period, Euphron of Sicyon is an important example of a Peloponnesian ruler who held his position constitutionally, as Lewis has shown, even though Xenophon describes his rule in negative and 'tyrannical' terms. ${ }^{94}$ Personal rule, as such, was not necessarily a fringe activity.

On the other hand, it is perhaps of greater consequence (particularly given the dominance of Athenian source material) that it is the women of those places which are more remote from Athens on whom our sources find it worthwhile to pass comment, especially given the difficulties their behaviour clearly presented to Athenian audiences. We have already noted the Athenian suspicion - and fascination - with ruling women, and perhaps for the Athenian mind they could only

${ }^{92}$ F.D. Harvey, 'Those Epirote women again (SEG, XV, 384)', CPh 64 (1969), 226-9.

${ }^{93}$ Pausanias gives his name as Meltas. A Melantas is named as basileus in ML 42, dating to about 450 B.C., although Meiggs and Lewis argue that the Melantas of the inscription is not to be identified with Meltas (as some have tried to do) and is just an eponymous official. Carlier (n. 1), 381-2 agrees, and thinks that the basileus of the inscription is an annual and eponymous magistrate. It was certainly the case that by the early sixth century, the Argive basileus shared sovereignty with other offices of state since the damiorgoi are also named in inscriptions (IG IV 493): Drews (n. 1), 58-63 (for date: L.H. Jefferey, The Local Scripts of Archaic Greece. A Study of the Origin of the Greek Alphabet and its Development from the Eighth to the Fifth Centuries BC, revised edn. [Oxford, 1990], 156-8).

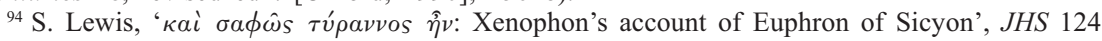
(2004), 65-74. 
belong on the edges of the Athenian world view and consciousness, and that was part of their liminality. ${ }^{95}$

The consideration of these ruling women is important in helping to elucidate the roles of rulers in the Archaic and Classical periods, and to show that the connections between the earlier periods and the Hellenistic world are stronger and more fundamental than is usually thought. ${ }^{96}$ What is also clear is that the Macedonian basileia, where women played an intrinsic role in the business of ruling, was not as unique as is often supposed. In fact, even in the age of the polis, ruling men need to be given a place again in the political landscape of the Archaic and Classical periods. But so also do their women. Although the women of ruling families in Archaic and Classical Greece were perhaps not as historically visible as the royal women of the Hellenistic courts, they preceded them and provided models for them and their behaviour. Shadowy figures they may appear to us now, but it was not as silent shadows that they brokered peace treaties, led armies, murdered husbands and made sure that it was their son (or grandson or brother) that held the sceptre of ruling power.

University of Exeter

LYNETTE G. MITCHELL 1.g.mitchell@exeter.ac.uk

${ }^{95}$ In a slightly different context (the story of the revenge of Hermotimus the eunuch) Simon Hornblower makes the point that the edges of the Greek world are the right kind of places for cultural confrontation; see S. Hornblower, 'Panionios of Chios and Hermotimos of Pedasa (Hdt. 8.104-6)', in P.S. Derow and R.C.T. Parker (edd.), Herodotus and his World. Essays from a Conference in Memory of George Forrest (Oxford, 2003), 48.

${ }^{96}$ Note, however, Hornblower (n. 21), 51, who strongly asserts: 'By looking back at the archaic phase of Greek history and forward to later autocrats ... we can remind ourselves that the democratic interludes of Greek history were not merely short but untypical.' Cf. Cartledge (n. 8), 29: 'Monarchy runs like a thread through Greek political history and thought ... It was never normal and normative, though.' 